Advances in Gene Technology: The Genome and Beyond -

Structural Biology for Medicine (Proceedings of the 2002 Miami

Nature Biotechnology Winter Symposium)

TheScientificWorld 2002, 2(S2), 3-4

ISSN 1532-2246; DOI 10.1100/tsw.2002.2

\title{
THE MECHANISM OF RNA INTERFERENCE AND THE TRANSPOSON SILENCING IN CAENORHABDITIS ELEGANS
}

Marcel Tijsterman, René Ketting, Sylvia Fischer, Femke Simmer, Titia Sijen, Kristy Okihara, Bas

Tops, Nadine Vastenhouw, and Ronald Plasterk

Hubrecht Laboratory, Uppsalalaan 8, 3584 CT Utrecht, the Netherlands

plasterk@niob.knaw.nl

INTRODUCTION. All isolates of $C$. elegans contain multiple transposable elements in their genome. These elements jump around freely in somatic cells, but transposition is fully silenced in the germline. In investigating the mechanism of transposon silencing, we found that it was mechanistically linked to another phenomenon: RNAi or RNA interference. This is the experimental silencing of gene expression by administration of double-stranded RNA.

METHOD. Mutants have been isolated that were defective in transposon silencing and/or in RNA interference. Several of these mutants have now been identified at the molecular level, thus defining essential components of the silencing machinery. The first biochemical analysis of the mechanism of silencing has also been initiated.

RESULTS. Our current picture of the pathway of silencing is shown in Fig. 1. (Marcel) Several of the mutator proteins will be discussed in detail. 


\section{A model:}

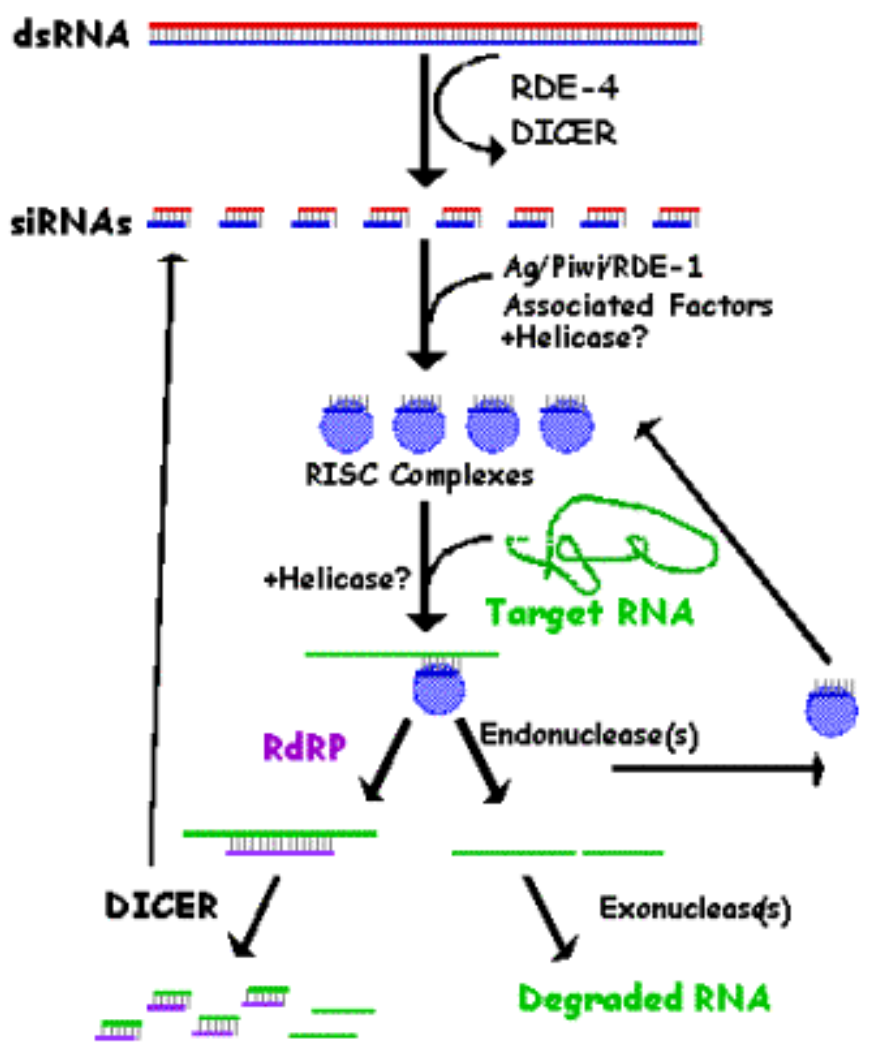

DISCUSSION. RNA interference is an experimental procedure that takes advantage of a mechanism that was probably meant for other purposes: the defense of the genome against the invasion of viruses and transposable elements. The human genome consists of approximately 50\% repetitive DNA, derived from previous invasions by transposons and viruses. It is a priori to be expected that complex organisms must have 'virus protection software', to limit such invasions to a minimum. This software must somehow be able to recognize the difference between self and nonself at the molecular level.

\section{REFERENCES}

1. Ketting, R.F., Haverkamp,T.H.A., van Luenen, H.G.A.M., and Plasterk, R.H.A. (1999) Cell 99, 133-141.

2. $\quad$ Ketting, R.F. and Plasterk, R.H.A. (2000) Nature 404, 296-298.

3. Ketting, R.F. and Plasterk, R.H.A. (2000) Curr. Opin. Genes Dev. 10, 562567.

4. Ketting, R.F., Fischer, S.E.J., Bernstein, E., Sijen, T., Hannon, G.J., and Plasterk, R.H.A. (2001) Genes Dev. 15(20), in press. 

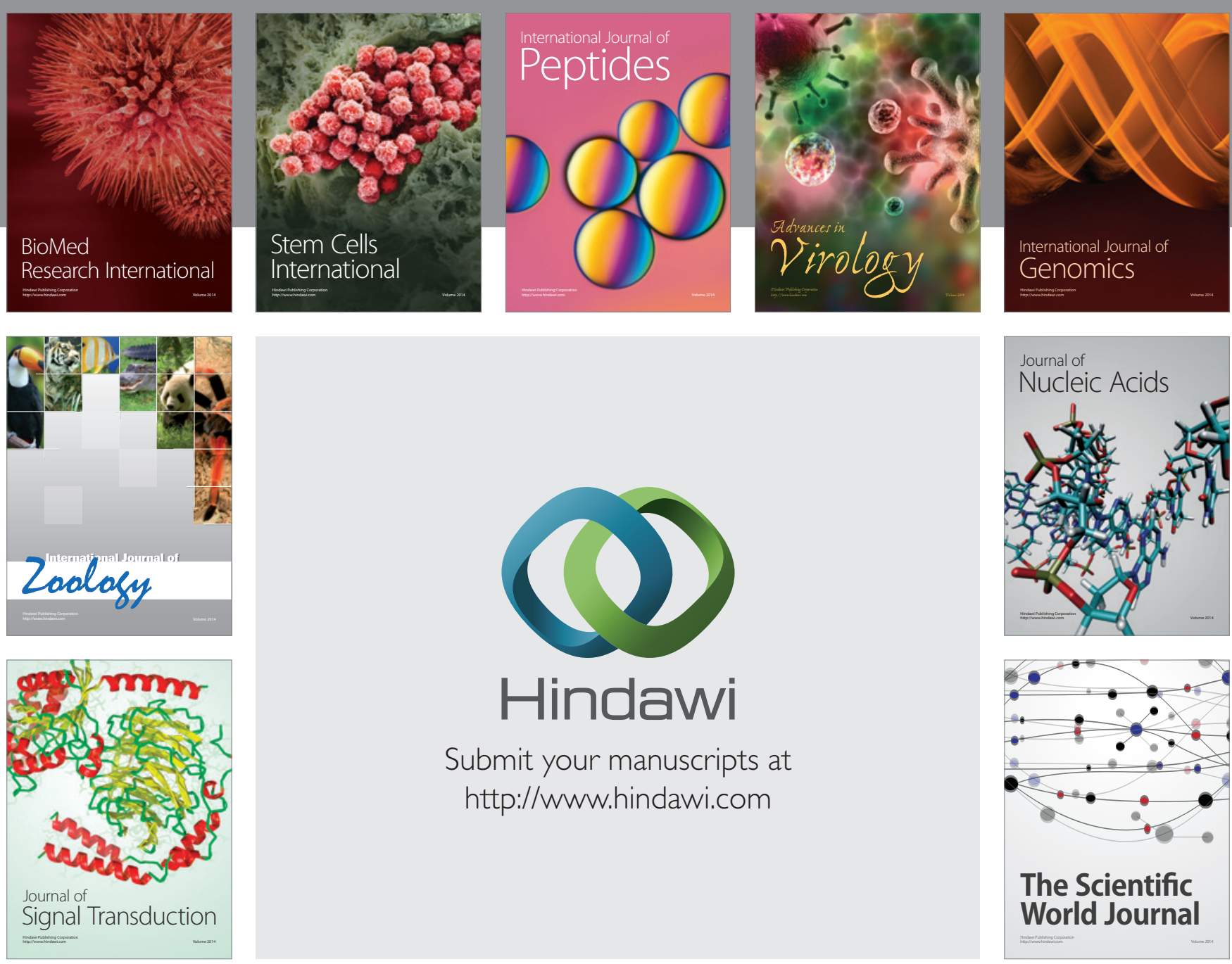

Submit your manuscripts at

http://www.hindawi.com
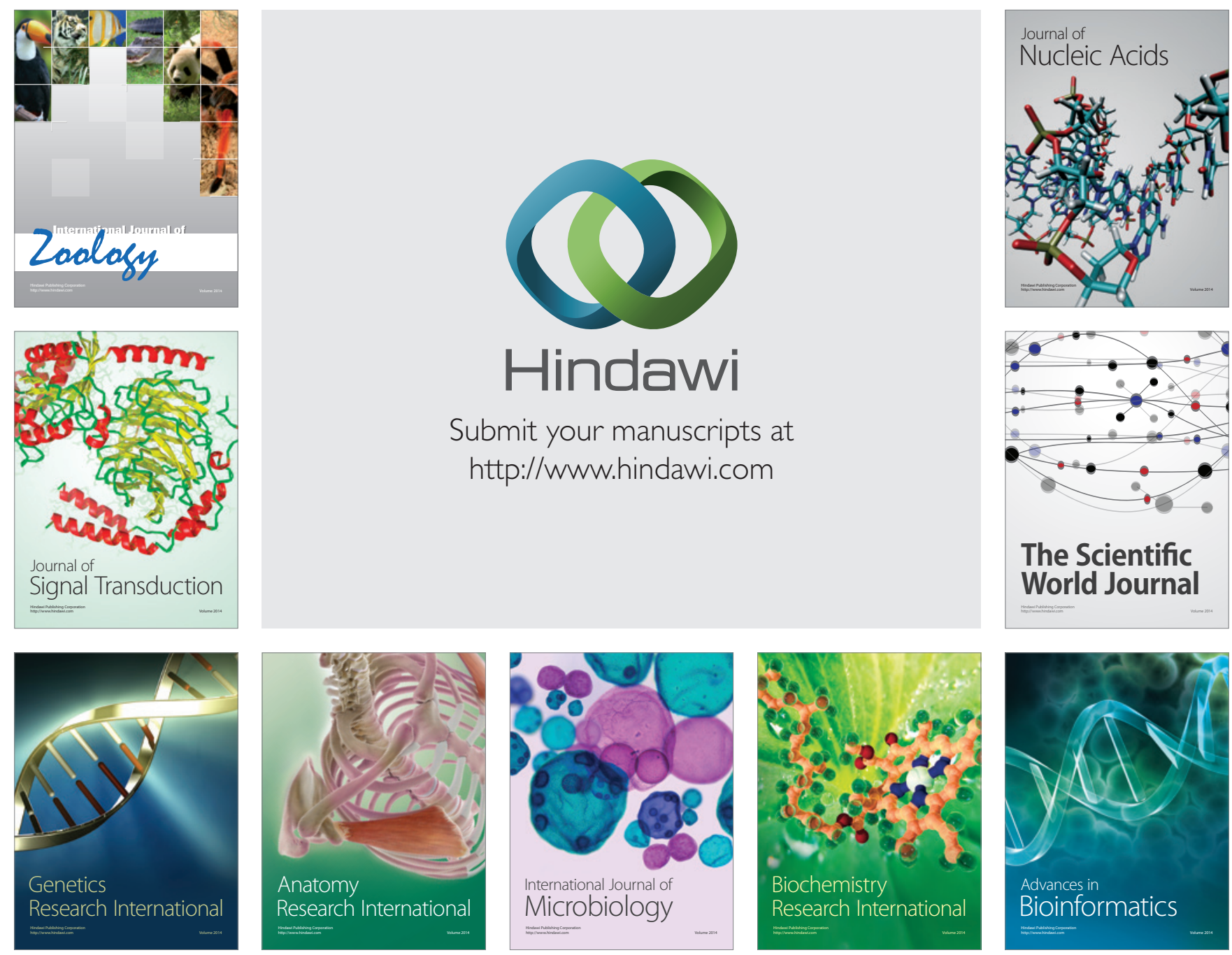

The Scientific World Journal
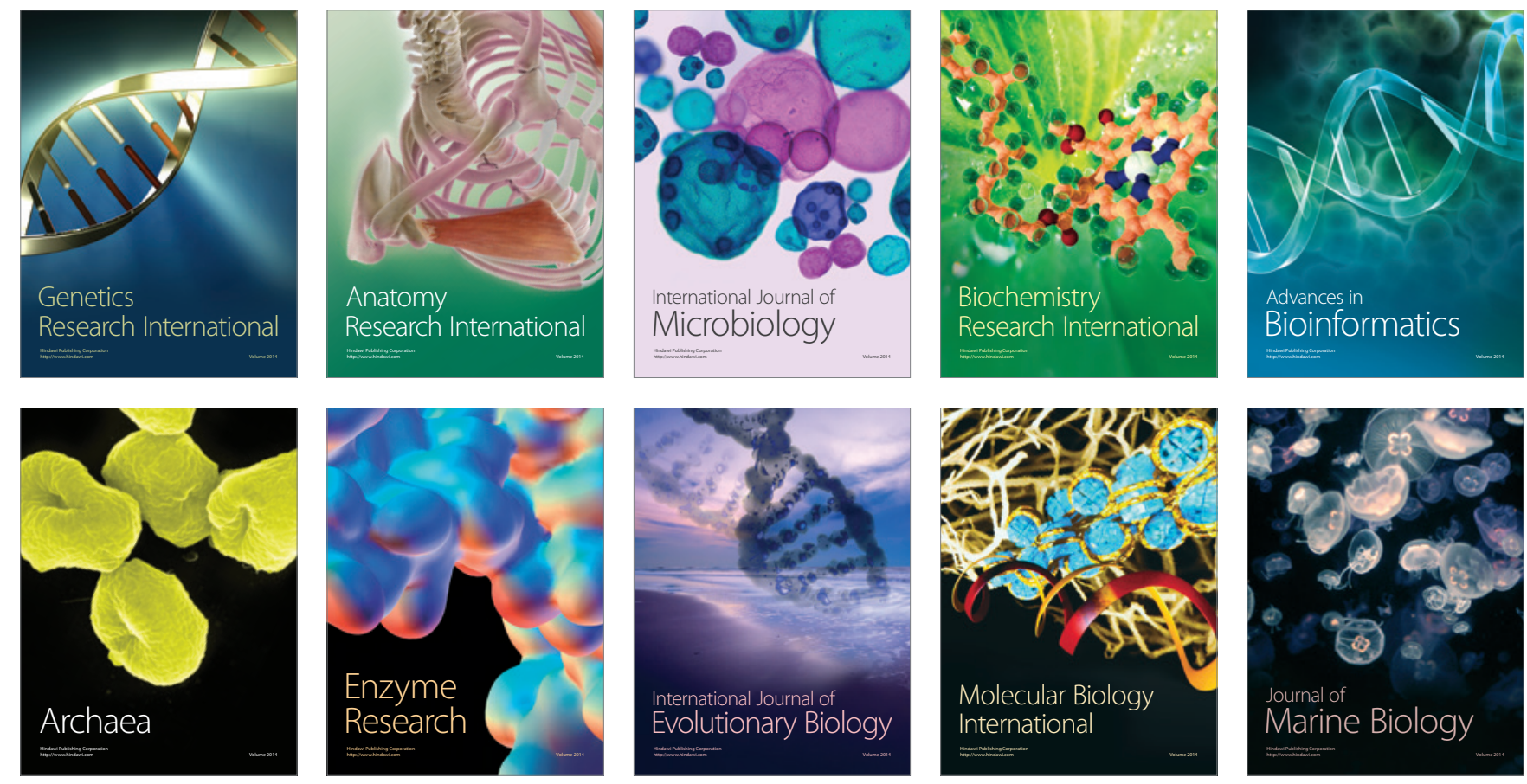